\title{
Notes and Announcements
}

\section{Saskatchewan Stroke Research Centre}

The World Health Organization (WHO) has designated the Saskatchewan Research Centre, Royal University Hospital, in Saskatoon, Saskatchewan, Canada as a WHO Collaborating Centre for Research and Training in Stroke Prevention, Epidemiology and Surveillance. The Centre was officially opened on September 27, 1995.

\section{Canada's First ON-Line Epilepsy Education Facility OPENS IN TORONTO}

The official launch ceremony of the opening of Canada's first on-line facility for epilepsy education was in November 1995. Offering unprecedented access to current information, this facility will enable people with epilepsy to make informed choices about their own care.

Open to people living with epilepsy and their families as well as health care professionals, the Hoechst Marion Roussel Epilepsy Education Centre will offer services that have never been available. The primary services of the Epilepsy Education Centre will be:

\section{1) On-line searching}

This Centre will be connected to the Internet, enabling instant access to current international epilepsy resources.

\section{2) Linking people with epilepsy}

Through its Web page, this Centre will provide a link to leading epilepsy sites on the Internet.

\section{3) Resource Centre}

The Centre also has a library stocked with current books, videos and brochures on epilepsy. Open to the public, topics of information will include seizure management, medications, surgery, human rights, psychological and social issues and research.

"This exciting project will give families with epilepsy, students and professionals, and the neurological community a new dimension of sophisticated patient care," said Dr. Richard Gladstone, President of the Association of Community Neurologists. "With education comes understanding and with knowledge comes hope. We shall all be able to resource the most up-to-date information anywhere and provide even better patient care and satisfaction. We hope the community will avail itself of this wonderful opportunity."

The Epilepsy Education Centre can be reached on the Internet at http://www.interlog.com/ rutheamt

For more information or personal interviews, contact: Yvonne Van Dinther or Diana Spremo, Optimum Public Relations, (416) 922-3050.

\section{The Think First Foundation of Canada}

The Think First Foundation of Canada is a national brain and spinal cord injury prevention program developed by America's neurosurgeons and adapted for a Canadian audience. Think First is sponsored by the Canadian Neurosurgical Society and the Canadian Association of Neuroscience Nurses. The Foundation is a voluntary non-profit organization governed by a 30 member Board of Directors made up of representatives from neurosciences, injury survivors, the corporate and business world. There are four components to the Think First program: school based education; reinforcement activities; general public education; and healthy public policy initiatives. The goal of the Foundation is to reduce the incidence of brain and spinal cord injuries among young Canadians who are most at risk for these catastrophic injuries. We also aim to make injury prevention a healthy lifestyle choice for Canada's youth.

The school program is the most significant aspect of the Foundation's work. The program focuses on injury prevention, and is directed at Canadian youth between the ages of 12-19 years old in senior elementary and high school throughout Canada. Our school program comprehensively addresses the major causes of brain and spinal cord injury and targets such behaviours as seat belt use, safe driving habits, avoidance of drinking and driving, avoidance of drinking and engaging in sports and other recreational activities, as well, the appropriate use of safety protective equipment. The program also addresses the appropriate bystander behaviour at the scene of an injury in order to prevent secondary injuries occurring. Volunteers are needed to participate in our school presentations, and for fundraising activities to support the program which is currently offered free of charge to all students.

Reinforcement strategies are an integral part of the Think First school program. In an attempt to keep the prevention message alive, students are encouraged to become involved in projects which promote healthy behavioural choices surrounding brain and spinal cord injury prevention. Currently senior elementary students within the Toronto Board of Education who have seen the presentations are participating in an injury prevention poster contest. It is our hope that posters designed by the students will create and convey community awareness about this subject.

Nationally, Think First is currently operating in seven provinces, British Columbia, Alberta, Saskatchewan, Ontario, Quebec, Nova Scotia and New Brunswick. School programs are currently ongoing in six of these, and to date we have reached approximately 10,000 students with our injury prevention message. Staff evaluations, as well as impact evaluations are performed after presentations are completed. This strategy helps us to focus and refine the process we utilize, as well as the content of the material we deliver to our audiences. It also helps us to determine whether our information is getting through to the target population. It is our objective to reach 750,000 Canadian students by the year 2000 .

The Foundation has received support from, and is grateful to its many corporate sponsors. But as is evident in these sparse economic times, partnerships and collaborative endeavour are vital in effectively maximizing the dissemination of such important information. In an attempt at effecting this type of collaboration, Think First Canada is currently pursuing partnerships 
with The Canadian Paraplegic Association and the Canadian Brain Injury Coalition on a national basis. Provincial partnerships with these organizations are also being planned.

The Foundation's message is not limited to the classroom. Our education campaign also includes a safe diving video which has been utilized in high school physical education classes, as well as community recreational facilities, i.e., public swimming pools across the country. Think First has also utilized numerous mass communication forums to promote its health enhancing messages. Several radio and television interviews and public service announcements have been, and continues to be aired.
THINK FIRST symbolizes organized neurosciences belief that if given the appropriate information about the severity of brain and spinal cord injuries, as well as the knowledge about their susceptibility to such injuries, young people would "think first" and "use their brain to protect their bodies".

For more information on the National THINK FIRST Program please contact: THINK FIRST FOUNDATION OF CANADA PENSER D'ARBORD, 399 Bathurst Street, McLaughlin Pavilion 2-435, Toronto, Ontario, Canada M5T 2S8; Toll Free 1-800-335-6076; Tel: (416) 603-5212; Fax: (416) 603-5298.

\section{Calendar of Events}

May 28 - 31, 1996. Canadian Neuro-Oncology Meeting will be held in Montreal, Quebec. Contact: Neuro-Oncology Secretariat, Conference Office, McGill University, 550 Sherbrooke St. West, West Tower, Suite 490, Montreal, Quebec, Canada H3A 1 B9. Telephone: (514)398-3770; Fax: (514)398-4854.

May 31 - June 2, 1996. Thirty Eighth Annual Scientific Meeting of the American Association for the Study of Headache will be held in San Diego, California. Contact: American Association for the Study of Headache, Suite 200, 875 Kings Highway, Woodbury, NJ USA 08098. Telephone: (609)845-1720; Fax: (609)384-5811.

June 15, 1996. Current Medical Management of Epilepsy Program will be held in La Jolla, California. Contact: Department of Academic Affairs, Box 403C, Scripps Clinic and Research Foundation, 10666 North Torrey Pines Road, La Jolla, California USA 92037. Telephone: (619)554-8556; Fax: (619)554-6310.

June 25 - 29, 1996. 31st Meeting of the Canadian Congress of Neurological Sciences will be held in London, Ontario, Canada. Contact: Congress Secretariat, Canadian Congress of Neurological Sciences, 810, 906 - 12th Ave. SW, Calgary AB Canada T2R 1K7. Telephone: (403)229-9544; Fax: (403)2291661; E-mail: brains@ccns.org

July 9 - 13, 1996. XXIV Meeting of the International Society for Pediatric Neurosurgery will be held in Ottawa, Canada. Contact: Shirley Verheyden and Associates, PO Box 84049, Pinecrest Post Office, Ottawa, Ontario, Canada K2C 3Z2.

July 24 - 29, 1996. Fifth International Conference on Alzheimer's Disease and Related Disorders will be held in Osaka, Japan. Contact: Masatoshi Takeda, Department of Neuropsychiatry, Osaka University Medical School, 2-2 Yamadaoka, Suita, Osaka 565, Japan. Telephone: 8168793051 ; Fax: 8168793059.

August 18 - 20, 1996. 35th Annual Scientific Meeting of the International Medical Society of Paraplegia will be held in Atlanta, Georgia, USA. Contact: Ms. Lesley Hudson, Co-ordinator IMSOP 96, Shepherd Center, 2020 Peachtree Road NW, Atlanta, Georgia USA 30309. Telephone: (404)350-7580; Fax: (404)355-1826
October 2 - 5, 1996. The American Association of Electrodiagnostic Medicine will be held in Minneapolis, Minnesota. Contact: American Association of Electrodiagnostic Medicine, 21 Second Street SW, Suite 103, Rochester MN USA 55902. Telephone: (507)288-0100. Fax: (507)288-1225.

October 13 - 16, 1996. The American Neurological Association Meeting will be held in Miami, Florida. Contact: American Academy of Neurology, 2221 University Avenue SE, Suite 335, Minneapolis, Minnesota USA. 55414. Telephone: (612)623-8115; Fax: (612)623-3504.

October 20 - 21, 1996. The International Symposium on Experimental Spinal Cord Repair and Regeneration will be held in Brescia, Italy. Contact: Studio Progress s.n.c., via C. Cattaneo, 51-25121 Brescia, Italia. Telephone: 030 290326; Fax: 030-40164.

October 27 - 30, 1996. Fifth International MRI Course will be held in Riyadh, Saudi Arabia. Contact: Department of Medical Studies, Riyadh Armed Forces Hospital, PO Box 7897, Riyadh 11159, Saudi Arabia. Telephone: 966-1 477 7714 ext 4933 or 4937; Fax: 966-1 476-0853.

March 16 - 23, 1997. World Brain Expo and Congress will be held in Vancouver, British Columbia, Canada. Contact: World Brain Expo and Congress, c/o Venue West Conference Services, \#645, 375 Water Street, Vancouver, BC Canada V6B 5C6. Telephone: (604)681-5226; Fax: (604)681-2503; Email: congress@venuewest.com

July 6 - 11, 1997. XIth International Congress of Neurological Surgery will be held in Amsterdam, The Netherlands. Contact: Amsterdam RAI - OBA, PO Box 77777,1070 MS Amsterdam, The Netherlands. Telephone: +31 (0)20 5491212; Fax: +31 (0)20 6464469 .

September 14 - 19, 1997. XVI World Congress of Neurology will be held in Buenos Aires, Argentina. Contact: General Secretariat, Congresos Internacionales SA, Moreno 584 - Piso 9, 1091 Buenos Aires, Argentina. Telephone: (54-1)3423216, 342-3283, 342-3408; Fax: (54-1)331-0223. 